\title{
New and regenerated production during a late summer bloom in an Arctic polynya
}

\author{
Marie-Ève Garneau ${ }^{1,4, *}$, Michel Gosselin ${ }^{1}$, Bert Klein $^{2,5}$, Jean-Éric Tremblay ${ }^{2}$, \\ Eric Fouilland ${ }^{3}$
}

\author{
${ }^{1}$ Institut des sciences de la mer (ISMER), Université du Québec à Rimouski, 310 Allée des Ursulines, Rimouski, \\ Québec G5L 3A1, Canada \\ ${ }^{2}$ Québec-Océan, Département de Biologie, Université Laval, Québec, Québec G1K 7P4, Canada \\ ${ }^{3}$ Écosystèmes Lagunaires, CNRS-UMR 5119, Université Montpellier II, Case 093, Place E. Bataillon, \\ 34095 Montpellier Cedex 5, France
}

${ }^{4}$ Centre d'etudes nordiques, Pavillon Abitibi-Price, Room 1202, Université Laval, Québec, Québec G1K 7P4, Canada

${ }^{5}$ Present address: 2063 rue Bourbonnière, Sillery, Québec G1T 1A9, Canada

\begin{abstract}
New and regenerated production were estimated from nitrate, ammonium and urea uptake in the highly productive North Water region (NOW, northern Baffin Bay) during the late summer bloom and its decline in early autumn 1999. Nitrogen uptake rates decreased due to a significant 4 -fold reduction of the average irradiance in the euphotic zone between these 2 periods. Nitrate availability also regulated the relative uptake of nitrate (ratio of nitrate uptake to total nitrogen uptake, or $f$-ratio) over spatial scales in early autumn. Stations located along the Greenland coast, which had relatively warm $\left(-0.5^{\circ} \mathrm{C}\right)$ and saline $(32.5)$ waters, had higher nitrate concentrations (153 vs. $51 \mathrm{mmol} \mathrm{N} \mathrm{m}^{-2}$ ) and $f$-ratios (0.36 vs. 0.16 ) than those of stations located on the Canadian side, where the euphotic zone was relatively colder $\left(-1.4^{\circ} \mathrm{C}\right)$ and less saline $(30.6)$. The $f$-ratios were also corrected for nitrogen uptake by heterotrophic bacteria using the results from experiments that employed specific metabolic inhibitors. The corrected $f$-ratio range of 0.24 to 0.41 considered only the fraction of the nitrogen uptake due to phytoplankton in order to obtain a more accurate estimate of new production. Based on this range, new production varied from 203 to 346 and 85 to $145 \mathrm{mg} \mathrm{C} \mathrm{m}{ }^{-2}$ $\mathrm{d}^{-1}$ in late summer and early autumn, respectively. For the entire sampling period, averaged new production was 132 to $228 \mathrm{mg} \mathrm{C} \mathrm{m}{ }^{-2} \mathrm{~d}^{-1}$; however, when the dissolved form was included, we estimated that new production may double to between 262 and $452 \mathrm{mg} \mathrm{C} \mathrm{m}^{-2} \mathrm{~d}^{-1}$. This estimate illustrates that dissolved forms can be significant and need to be considered. When combining our results with those from the literature, new production in the NOW in 1998-99 amounted to between 143 and $152 \mathrm{~g} \mathrm{C} \mathrm{m}^{-2} \mathrm{yr}^{-1}$, suggesting that $60 \%$ of the total annual primary production may potentially be exported from the euphotic zone. This study completes the first annual time series of new production in a high-latitude ecosystem.
\end{abstract}

KEY WORDS: Late summer bloom - Nitrogen uptake rate $\cdot$ New production - Export carbon production · North Water Polynya

\section{INTRODUCTION}

In polar regions, top predators such as birds and mammals aggregate in polynyas, i.e. regions of open water or thin ice cover surrounded by consolidated sea ice (Stirling 1997). In comparison with adjacent icecovered regions, primary productivity in polynyas is high (Smith et al. 1997). The North Water (NOW; see Fig. 1) in northern Baffin Bay is the most important recurring Arctic polynya in terms of size and number of bird and mammal species (Stirling 1997) and is among the most productive marine systems north of the Arctic Circle (Klein et al. 2002, Tremblay et al. 2002a). Phytoplankton production in the NOW, which 
extends from April to September (Klein et al. 2002), is based on an exceptionally long-lasting bloom of the diatoms Thalassiosira spp. and Chaetoceros spp. (Booth et al. 2002). The prolonged bloom is apparently sustained by a continuously advected nutrient supply in addition to uninterrupted solar radiation (Lovejoy et al. 2002). In spring and early summer, low sinking velocities of the phytoplankton community lead to a potentially high transfer of particulate primary production $(66 \%$ ) to metazoans (Mei et al. 2003), which could explain the abundance of animals in the region. The end of the open-water season is also of substantial ecological interest since an increase in Chaetoceros socialis (Mostajir et al. 2001, Booth et al. 2002) associated with a second peak of sedimentation (Caron et al. 2004) suggested the existence of an autumn bloom, which is usually a feature of temperate and boreal marine systems (Wassmann et al. 1991).

Prior to this study, time series of nitrogen uptake and primary production in the NOW covered the very productive spring-summer period (11 April to 21 July 1998) when the overall average of new production rates was $1.1 \mathrm{~g} \mathrm{C} \mathrm{m}^{-2} \mathrm{~d}^{-1}$, but this value does not include the autumn bloom (Tremblay et al. 2002b, 2006). Autumn sampling is also lacking for the Northeast Water Polynya (NEW Polynya: 77 to $78^{\circ} \mathrm{N}, 5$ to $10^{\circ} \mathrm{W}$ ), the only other arctic region where time series of nitrate, ammonium and urea uptake have been established (Smith 1995, Smith et al. 1997). Our study was undertaken within the context of the International NOW Polynya Study and presents nitrogen uptake rates from the end of the summer to early autumn. Our specific objectives were to evaluate the spatial and temporal variations in nitrogen uptake, relate these to environmental factors, and quantify new (nitratebased) production in order to complete the annual cycle.

Two distinct water masses occupy the NOW: (1) the relatively warm nitrate-rich Atlantic water of the West Greenland Current, which enters from the southeast and reaches as far as $78^{\circ} \mathrm{N}$ on the eastern side of the NOW, and (2) the southward flow of cold and fresh arctic water along the Canadian coast (Melling et al. 2001, Mostajir et al. 2001). For this reason, we hypothesized that the different physical and chemical characteristics of these 2 water masses should explain the spatial distribution of nitrogen uptake, with the highest rates possibly located in the warmest waters.

Besides characterizing the physiological performance of the phytoplankton in a given environmental setting, studies of nitrogen uptake provide useful information on the potential fate of primary production, i.e. the fraction of primary production that is potentially exportable from the euphotic zone. Nitrate-based primary production, or new production (Dugdale \&
Goering 1967), is assumed to be quantitatively equivalent to the potential export of organic carbon out of the euphotic zone to depth or toward higher trophic levels in a steady-state system (Eppley \& Peterson 1979). The remaining primary production based on ammonium and urea is assumed to be remineralized within the euphotic zone and is known as regenerated production.

Several approaches have been used to determine new and export production, but they are rarely performed and compared during the same study (Falkowski et al. 2003). In this study, we compare different methods used to estimate new and export production, giving special attention to the uptake of inorganic nitrogen by heterotrophic bacteria and the potential export of dissolved organic matter.

\section{MATERIALS AND METHODS}

Sampling. Samples were collected in the NOW (Fig. 1) from the icebreaker CCGS 'Pierre Radisson' in 1999. Ten stations were visited during Leg 1 (late summer: 27 August to 10 September) and 24 stations during Leg 2 (early autumn: 11 September to 1 October). Ice cover (\%) and general weather conditions (e.g. overcast) were determined visually. Incident irradiance (photosynthetically active radiation, PAR, 400 to $700 \mathrm{~nm}$ ) was measured at $15 \mathrm{~min}$ intervals during the cruise with a LI-COR 192SA quantum sensor. When possible, a vertical PAR profile was obtained a day prior to sampling using a PNF-300 radiometer (Biospherical Instruments). Otherwise, a Secchi disk was used to estimate the diffuse light attenuation coefficient $\left(K_{\mathrm{d}}\right)$. Water samples were collected at 7 optical depths $(100,50,30,20,10,1$ and $0.1 \%$ of surface PAR) with $10 \mathrm{l}$ Niskin water bottles (Brooke Ocean Technology) fixed on a rosette sampler (General Oceanics) equipped with a high precision CTD probe (Falmouth Scientific). Given that nitrogen uptake at $1 \%$ of surface PAR is frequently reported to be a significant proportion of the maximal uptake rate within the water column of polar systems (Smith \& Harrison 1991), the bottom of the euphotic zone $\left(Z_{\text {eu }}\right)$ in this study was defined as the depth receiving $0.1 \%$ of the surface PAR.

Chemical and biological measurements. Samples for dissolved inorganic and organic nutrients were filtered through pre-combusted $\left(500^{\circ} \mathrm{C}\right.$ for $\left.5 \mathrm{~h}\right)$ Whatman GF/F filters. The filtrate was immediately analyzed for ammonium $\left(\mathrm{NH}_{4}{ }^{+}\right)$using the colorimetric method (Parsons et al. 1984). The remaining filtrate was immediately frozen at $-80^{\circ} \mathrm{C}$ in acid-cleaned polypropylene cryogenic vials and processed within 2 mo for the determination of silicic acid $\left(\mathrm{Si}[\mathrm{OH}]_{4}\right)$, 


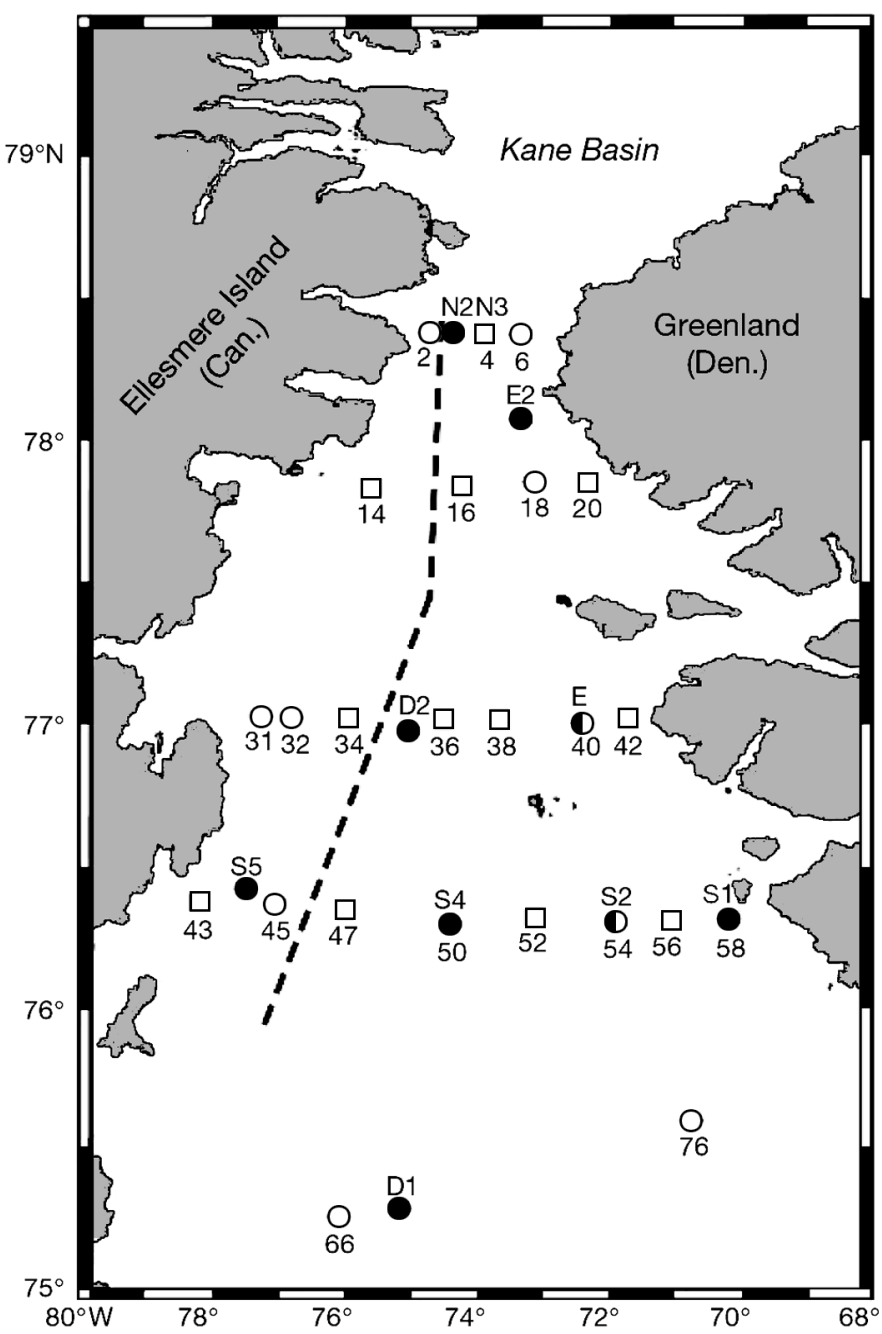

Fig. 1. Sampling station locations in the North Water (NOW) in late summer $(\bullet)$ and early autumn $(O)$. Stations sampled in early autumn for nutrient concentration only ( $\boldsymbol{\square})$. Dashed line is the boundary between 2 groups of stations in early autumn (see 'Results')

phosphate $\left(\mathrm{PO}_{4}{ }^{3-}\right)$, nitrate plus nitrite $\left(\mathrm{NO}_{3}{ }^{-}+\mathrm{NO}_{2}{ }^{-}\right)$, and nitrite $\left(\mathrm{NO}_{2}^{-}\right)$using a Technicon II Autoanalyzer (Strickland \& Parsons 1972), and for the determination of urea using the diacethyl monoxime method (Price \& Harrison 1987). Samples for particulate organic carbon (POC) and nitrogen (PON) were filtered onto precombusted Whatman GF/F filters. Filters were then stored at $-80^{\circ} \mathrm{C}$ until analysis with a Perkin-Elmer 2400 CHN Analyzer. Samples for chlorophyll a were filtered onto Whatman GF/F filters (total phytoplankton chlorophyll a: chl a) and onto Nuclepore polycarbonate $5 \mu \mathrm{m}$ membranes (large phytoplankton: chl $a_{\mathrm{L}}$ ). Concentrations of chl a were determined using a Turner Designs fluorometer (model 10-005R) after $24 \mathrm{~h}$ extractions in $90 \%$ acetone in the dark at $5^{\circ} \mathrm{C}$ without grinding (Parsons et al. 1984).
Nitrogen uptake rate measurements. At selected stations (see Fig. 1), uptake rates of nitrate, ammonium and urea by the planktonic community were measured at the 7 optical depths using the ${ }^{15} \mathrm{~N}$-labelling method described by Dugdale \& Wilkerson (1986). Stock solutions of nitrate $\left(\mathrm{K}^{15} \mathrm{NO}_{3}, 99\right.$ atom \%), ammonium $\left(\left[{ }^{15} \mathrm{NH}_{4}\right]_{2} \mathrm{SO}_{4}, 99\right.$ atom \%) and urea $\left({ }^{15} \mathrm{~N}\right.$-urea, 95 atom $\%$ ) were stored in acid-cleaned Teflon bottles. Separate additions of the ${ }^{15} \mathrm{~N}$ tracers were made to samples in acid-cleaned $500 \mathrm{ml}$ polycarbonate bottles. Final tracer concentrations during all experiments were $0.1 \mu \mathrm{mol} \mathrm{l}^{-1}$ for $\mathrm{NO}_{3}{ }^{-}$and $\mathrm{NH}_{4}{ }^{+}$, and $0.05 \mu \mathrm{mol} \mathrm{l}{ }^{-1}$ for urea.

The bottles containing tracer were placed in a Plexiglas deck incubator set up on a black board and equipped with tubes wrapped with neutral density screens (LEE Filters) to simulate irradiance at the depth of sample collection. Tubes simulating $\leq 30 \%$ PAR were wrapped with 1 layer of blue filter to mimic vertical changes in spectral quality (Smith et al. 1997). Running seawater pumped from a depth of about 5 to $7 \mathrm{~m}$ circulated through the incubator to maintain the temperature at that of the upper mixed layer. Incubations were carried out for $4 \mathrm{~h}$ from 06:00 to 10:00 h local time (LT). After incubation, samples were filtered onto precombusted Whatman GF/F filters and stored frozen at $-80^{\circ} \mathrm{C}$. During preparation, inoculation and filtration, samples were protected from strong and ambient light. Prior to sample analysis, filters were dried at $60^{\circ} \mathrm{C}$ for $24 \mathrm{~h}$ and pelletized. Samples were then analyzed for ${ }^{15} \mathrm{~N}$ isotope ratios and PON using a mass spectrometer (Delta Plus, Thermo Finnigan Mat) coupled with an elemental analyzer (CE Instrument model 1110). Absolute rates of nitrogen uptake ( $\rho$, expressed in mmol $\mathrm{N} \mathrm{m}^{-3} \mathrm{~h}^{-1}$ ) were calculated according to the constant transport model (Grunseich et al. 1980). No difference in nitrate uptake was observed between night and day measurements (Fouilland et al. 2007), and it was assumed that nitrate, ammonium and urea uptake occurred over the whole $24 \mathrm{~h}$ cycle.

For most of the samples, the concentrations of isotope additions were greater than $10 \%$ of ambient ammonium and urea concentrations. This ${ }^{15} \mathrm{~N}$ enrichment might have induced an overestimation of the in situ ammonium and urea uptake rates. The potential effect of substrate enhancement on nitrogen uptake was estimated using the methodology proposed by MacIsaac \& Dugdale (1972). We used values of halfsaturation constants $\left(K_{\mathrm{s}}\right)$ for ammonium and urea of 0.2 and $0.3 \mu \mathrm{M}$, respectively, measured in northern Baffin Bay in summer for the whole planktonic community (Smith \& Harrison 1991). On average, our rates of ammonium and urea uptake were overestimated by $53 \%$. However, this overestimation may in turn have been balanced by an isotope dilution effect that may underestimate uptake rates. We evaluated the poten- 
tial isotope dilution effect for ammonium and urea measurements based on the model of Kanda et al. (1987). The uptake rates of regenerated nitrogen were underestimated by an average of 8 or $20 \%$ when we assumed that regeneration rates are, respectively, equal to or twice the uptake rates usually observed in marine systems (Kanda et al. 1987). Isotope dilution effects on nitrate uptake are not well known but are probably less important than for ammonium (Harrison et al. 1985). Therefore, ammonium and urea uptake rates in the present study may have been overestimated by 33 to $45 \%$ due to a greater effect of ${ }^{15} \mathrm{~N}$ enrichment than of the isotope dilution.

Calculations. Daily irradiance averaged over the euphotic zone $\left(E_{0}-Z\right.$ eu $)$ was calculated using the equation of Riley (1957). The depth of the surface mixed layer $\left(Z_{\mathrm{m}}\right)$ was defined as the depth where the potential density showed a difference of $>0.03 \mathrm{~kg} \mathrm{~m}^{-3}$ per meter. At stations where irregular variations in the density profile occurred, the surface mixed layer was estimated by visual inspection of the CTD profiles. Water temperatures $\left(T_{0-Z e u}\right)$, salinity $\left(S_{0-Z e u}\right)$ and nutrient concentrations $\left(\mathrm{mmol} \mathrm{m}^{-3}\right)$ at the 7 optical depths were integrated over the euphotic zone and divided by $Z_{\text {eu }}$ to obtain mean values for the euphotic zone. Concentrations of nutrients $\left(\mathrm{mmol} \mathrm{m}^{-2}\right)$, PON and $\mathrm{chl}$ a $\left(\mathrm{mg} \mathrm{m}^{-2}\right)$, as well as absolute rates of nitrogen uptake ( $\mathrm{mmol} \mathrm{N} \mathrm{m}^{-2} \mathrm{~h}^{-1}$ ), were integrated over the euphotic zone. To average mean daily production rates of Legs 1 and 2, weighted averages were computed according to Eq. (4.2) of Sokal \& Rohlf (1981). This calculation takes into account that the duration of the 2 sampling periods was different (i.e. 14 and $21 \mathrm{~d}$ for Legs 1 and 2, respectively).

Statistical analysis. Kendall's rank correlation coefficient $\left(\tau_{i}\right.$ Zar 1999) was used to determine the relationships between environmental factors (i.e. day length, $T_{0-Z \text { eu }}, S_{0-Z e u}, E_{0-Z e u}, Z_{\text {eu }}, Z_{\mathrm{m}}$ and nutrient concentrations), nitrogen uptake rates and chl a concentrations. The R software (Legendre \& Vaudor 1991) was used to analyze the horizontal distribution of the variables by spatial autocorrelation (Legendre \& Legendre 1998) using the $I$ coefficient, which is a measure of randomness in the spatial distribution of a variable. The mathematical expectancy of $I$, under the hypothesis of a completely random spatial distribution, is $E(I)=-(n-1)^{-1}$, where $\mathrm{n}$ is the number of values. Sturge's rule was used to define the number of classes in correlograms (Legendre \& Legendre 1998) and tests of significance were 2-tailed. The R software was also used to group stations using complete-linkage cluster analysis of a matrix of similarities (Gower's coefficient: $S_{15}$ ) between all pairs of stations (Legendre \& Legendre 1998). Linkage cluster analysis was completed using the $f$-ratio (ratio of nitrate uptake to total nitrogen uptake) and the chl $a_{\mathrm{L}}$ :chl a ratio. Differences between sampling periods and groups of stations were tested using Student's $t$-test; a MannWhitney $U$-test was used whenever normality and homogeneity of variance tests failed (Zar 1999).

\section{RESULTS}

\section{Physical environment}

From August to October 1999, physical variables varied over large spatial and temporal scales in the NOW. In late summer, all sampling stations were free of ice with the exception of Stns D2 and N2/N3, where the ice cover was 10 and $5 \%$, respectively (Table 1). In early autumn, especially from 20 September onwards, there was active ice formation that, together with the advection of ice from Kane Basin, resulted in up to $95 \%$ ice cover in the northern sector $\left(\geq 70^{\circ} \mathrm{N}\right)$ of the NOW.

During the whole expedition, $28 \%$ of the sampling days were sunny, 36\% were overcast and $36 \%$ had variable cloud cover. Day length decreased from $18.5 \mathrm{~h}$ at the beginning of sampling on 29 August to $10 \mathrm{~h}$ on 1 October (Table 1). Mean irradiance in the euphotic zone showed a 2-fold decline $(p<0.05)$ between the 2 sampling periods (Table 1 ) as a result of the seasonal decrease in incident solar radiation, increase in cloud cover and sea-ice formation. Mean water temperature in the euphotic zone also decreased $(p<0.05)$ between the late summer and early autumn periods (Table 1). However, there was little variation in the mean salinity of the euphotic zone or in the depth of the euphotic zone or surface mixed layer (Table 1 ). The ratio of $Z_{\mathrm{m}}$ to $Z_{\text {eu }}$ never exceeded 0.83 (mean 0.39) except at Stn E2, implying that the euphotic zone was deeper than the surface mixed layer for most of the NOW.

As previously noted for surface waters by Mostajir et al. (2001), temperature and salinity in the upper water column displayed a well-defined pattern in the NOW. Spatial autocorrelation analysis confirmed the presence of a strong north-south gradient in the euphotic zone for mean values of (1) water temperature during early autumn and (2) salinity for both the late summer and early autumn periods (Table 1 ). The upper water column was significantly fresher $(30.2<S<32.2)$ and cooler $\left(T \leq-1.0^{\circ} \mathrm{C}\right)$ in the northwestern sector of the NOW than in the southeastern sector $(32.3<S<33.2$; $T>-0.5^{\circ} \mathrm{C}$ ) (Table 1). No other physical variable showed a significant spatial pattern.

\section{Nutrients}

At stations where nitrogen uptake was determined, nitrate was the most abundant nitrogenous nutrient in the euphotic zone over the study period, with con- 
Table 1. Environmental conditions in the euphotic zone at stations (north to south) sampled in the North Water (NOW) during late summer and early autumn. $E_{0-\text { zeu }}$ average irradiance; $T_{0}$-Zeu : mean temperature; $S_{0-Z e u}$ mean salinity; $Z_{\text {eu}}$ : euphotic zone depth; $Z_{\mathrm{m}}$ : surface mixed layer depth; PON: particulate organic nitrogen; POC: particulate organic carbon; nd: no data available

\begin{tabular}{|c|c|c|c|c|c|c|c|c|c|c|c|}
\hline Station & Date & $\begin{array}{l}\text { Ice cover } \\
(\%)\end{array}$ & $\begin{array}{l}\text { Day length } \\
\text { (h) (r }\end{array}$ & $\begin{array}{l}\text { th } \quad E_{0-Z e u} \\
\text { (mol photons } \mathrm{m}^{-2} \mathrm{~d}^{-1}\end{array}$ & $\begin{array}{l}T_{0} \text {-Zeu } \\
-1) \quad\left({ }^{\circ} \mathrm{C}\right)\end{array}$ & $\begin{array}{l}S_{0-Z \mathrm{eu}} \\
\text { (PSU) }\end{array}$ & $\begin{array}{l}Z_{\mathrm{eu}} \\
(\mathrm{m})\end{array}$ & $\begin{array}{l}Z_{\mathrm{m}} \\
(\mathrm{m})\end{array}$ & $\begin{array}{c}\mathrm{PON} \\
\left(\mathrm{mg} \mathrm{m}^{-2}\right)\end{array}$ & $\begin{array}{c}\text { POC:PON } \\
(g: g)\end{array}$ & $\begin{array}{l}\mathrm{N} \mathrm{Chl} \mathrm{a} \\
{\left(\mathrm{mg} \mathrm{m}^{-2}\right.}^{-2}\end{array}$ \\
\hline \multicolumn{12}{|c|}{ Leg 1: late summer } \\
\hline N2/N3 & 4 Sep & 5 & 17.5 & 2.6 & -1.0 & 30.2 & $22^{\mathrm{a}}$ & 13 & 615 & 8.9 & 16 \\
\hline $\mathrm{E} 2$ & 3 Sep & 0 & 17.8 & 2.9 & -0.8 & 31.6 & 28 & 29 & 1771 & 5.9 & 121 \\
\hline E1 & $6 \mathrm{Sep}$ & 0 & 16.3 & 1.1 & 0.8 & 32.6 & 36 & 14 & 1923 & 5.9 & 83 \\
\hline D2 & 1 Sep & 10 & 17.0 & 1.1 & 0.4 & 31.4 & $22^{\mathrm{a}}$ & 13 & 773 & 8.5 & 43 \\
\hline S5 & 30 Aug & 0 & 17.3 & 3.6 & -0.2 & 32.4 & $73^{\mathrm{a}}$ & 12 & 1277 & 9.9 & 36 \\
\hline S4 & 29 Aug & 0 & 18.5 & 2.3 & -0.5 & 32.0 & 51 & 14 & 1617 & 10.4 & 77 \\
\hline $\mathrm{S} 2$ & $7 \mathrm{Sep}$ & 0 & 15.8 & 1.6 & 0.1 & 32.6 & 59 & 7 & 1605 & 7.4 & 42 \\
\hline $\mathrm{S} 1$ & $8 \mathrm{Sep}$ & 0 & 15.3 & 1.0 & 0.6 & 32.4 & 44 & 7 & 1230 & 6.9 & 58 \\
\hline $\mathrm{S} 4 \mathrm{~b}$ & $10 \mathrm{Sep}$ & 0 & 15.3 & 0.8 & 1.0 & 32.1 & 33 & 7 & 1047 & 7.8 & 33 \\
\hline D1 & 27 Aug & 0 & nd & nd & 0.9 & 32.8 & $49^{a}$ & 17 & nd & nd & 46 \\
\hline \multicolumn{2}{|c|}{ Mean \pm SD } & $2 \pm 3$ & $16.7 \pm 1.1$ & $1.9 \pm 1.0$ & $0.2 \pm 0.7$ & $32.0 \pm 0.8$ & $42 \pm 17$ & $13 \pm 6$ & $1318 \pm 450$ & $8.0 \pm 1.6$ & $657 \pm 32$ \\
\hline \multicolumn{12}{|c|}{ Leg 2: early autumn } \\
\hline 2 & 11 Sep & 50 & 14.5 & 1.3 & -1.6 & 30.5 & 30 & 10 & 1390 & 6.1 & 146 \\
\hline 6 & $13 \mathrm{Sep}$ & 15 & 14.8 & 1.3 & -1.0 & 32.2 & $30^{\mathrm{a}}$ & 15 & 1815 & 5.8 & 124 \\
\hline 18 & $24 \mathrm{Sep}$ & 40 & 11.8 & 1.0 & -1.5 & 31.3 & 42 & 12 & nd & nd & 104 \\
\hline 15 & $25 \mathrm{Sep}$ & 90 & 11.0 & 0.6 & -1.7 & 31.0 & 38 & 28 & 1449 & 6.2 & 116 \\
\hline 31 & 23 Sep & 95 & 11.5 & 0.6 & -1.2 & 30.2 & 63 & 8 & 1182 & 7.5 & 45 \\
\hline 32 & 22 Sep & 90 & 12.0 & 1.0 & -1.2 & 30.6 & 63 & 20 & 1738 & 7.0 & 33 \\
\hline 40 & 21 Sep & 90 & 12.3 & 1.3 & -0.1 & 32.7 & 45 & 6 & 1523 & 7.3 & 91 \\
\hline 45 & $18 \mathrm{Sep}$ & 1 & 12.5 & nd & -1.3 & 30.6 & $52^{\mathrm{a}}$ & 20 & 1169 & 7.4 & 64 \\
\hline 54 & 19 Sep & 0 & 12.5 & 0.9 & 0.3 & 32.3 & 35 & 29 & 1441 & 5.7 & 95 \\
\hline 76 & 1 Oct & 0 & 10.0 & 0.5 & -0.4 & 33.2 & 48 & 19 & 1322 & 7.3 & 101 \\
\hline 66 & 30 Sep & 0 & 10.3 & 0.9 & -0.4 & 33.0 & $54^{\mathrm{a}}$ & 11 & 1130 & 7.4 & 49 \\
\hline \multicolumn{2}{|c|}{ Mean \pm SD } & $42 \pm 41$ & $12.1 \pm 1.5$ & $0.9 \pm 0.3$ & $-0.9 \pm 0.6$ & $31.6 \pm 1.1$ & $45 \pm 12$ & $16 \pm 8$ & $1416 \pm 232$ & $6.8 \pm 0.7$ & $788 \pm 36$ \\
\hline
\end{tabular}

centrations ranging from 0.16 to $6.90 \mathrm{mmol} \mathrm{m}^{-3}$ (mean $2.83 \mathrm{mmol} \mathrm{m}^{-3}$ ). Nitrate inventories in the euphotic zone varied from 4 to $504 \mathrm{mmol} \mathrm{m} \mathrm{m}^{-2}$ (mean $134 \mathrm{mmol} \mathrm{m}^{-2}$ ), with lower concentrations in the northwestern sector of the NOW (Fig. 2A). Ammonium concentrations varied from below the detection limits to $0.56 \mathrm{mmol} \mathrm{m}^{-3}$ (mean $0.29 \mathrm{mmol} \mathrm{m}^{-3}$ ). Over the euphotic zone, ammonium concentrations were about 10 times lower than nitrate concentrations, ranging from $>0$ to $35 \mathrm{mmol} \mathrm{m}^{-2}$ (Fig. 2B). Urea concentrations were low, from below the detection limits to $0.32 \mathrm{mmol}$ $\mathrm{m}^{-3}$, with a mean of $0.13 \mathrm{mmol} \mathrm{m} \mathrm{m}^{-3}$. Inventories of urea over the euphotic zone reached a maximum of $23 \mathrm{mmol} \mathrm{m}^{-2}$. Urea concentrations were below the detection limits at 4 stations (see Fig. 2C). At stations where uptake rates were estimated, neither urea nor ammonium showed a significant spatial pattern and there was no significant temporal trend in the concentration of any nitrogen source.

However, the complete data set reveals that the nitrate inventory changed over the NOW region during the study period. Between the 2 sampling periods, the nitrate inventory decreased by 73 to $92 \%$ at almost all stations; the exceptions were Stns N2/N3 and E1/40, where nitrate concentrations increased by
20 and $40 \%$ (Fig. 2A), respectively. From late summer to early autumn, the nitrate inventory in the euphotic zone decreased (Mann-Whitney $U$-test, $\mathrm{p}<0.05$ ) from a median value of 124 to $67 \mathrm{mmol} \mathrm{m}^{-2}$. The complete data set did not show any seasonal difference in ammonium or urea inventories.

Silicic acid was the most abundant nutrient in late summer-early autumn 1999. Minimum, mean and maximum concentrations in the euphotic zone were $0.7,4.6$ and $12.2 \mathrm{mmol} \mathrm{m}^{-3}$, respectively. Phosphate concentrations ranged from 0.2 and $1.2 \mathrm{mmol} \mathrm{m}^{-3}$ (mean $0.6 \mathrm{mmol}$ $\left.\mathrm{m}^{-3}\right)$. The average $\left(\mathrm{NO}_{3}{ }^{-}+\mathrm{NH}_{4}{ }^{+}+\right.$urea $): \mathrm{Si}(\mathrm{OH})_{4}$ and $\left(\mathrm{NO}_{3}{ }^{-}+\mathrm{NH}_{4}{ }^{+}+\right.$urea): $\mathrm{PO}_{4}{ }^{3-}$ atomic ratios were 0.7 and 5.6, respectively. These values are lower than the Redfield ratios of 1.1 and 16 (Redfield et al. 1963), which implies that dissolved nitrogen was the limiting macronutrient for phytoplankton cells in the NOW.

\section{Phytoplankton biomass and particulate organic matter}

During the study, total phytoplankton biomass in the euphotic zone varied between 0.07 and $5.2 \mathrm{mg}$ chl $a$ $\mathrm{m}^{-3}$. Depth-integrated $\mathrm{chl} a$ and PON ranged from 

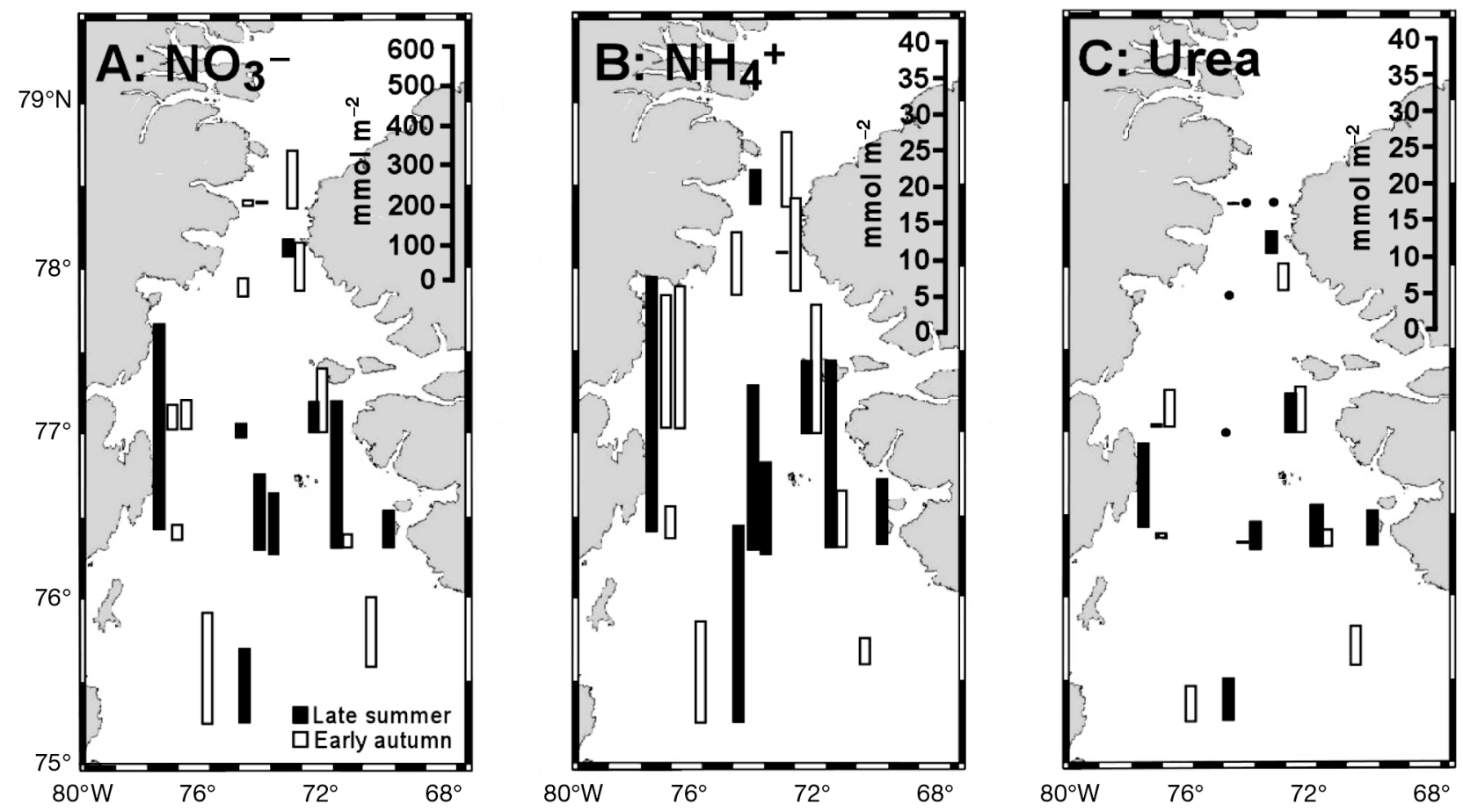

Fig. 2. Spatial variation in concentrations of (A) nitrate $\left(\mathrm{NO}_{3}^{-}\right)$, (B) ammonium $\left(\mathrm{NH}_{4}^{+}\right)$and (C) urea in the NOW in late summer (black bars) and early autumn (open bars). Values were depth-integrated from the surface to $0.1 \%$ of surface irradiance. Black dots: urea concentrations below the detection level. Note different scale for nitrate

16 to $146 \mathrm{mg} \mathrm{m}^{-2}$ and from 615 to $1923 \mathrm{mg} \mathrm{m}^{-2}$, respectively (Table 1). There was no significant difference in chl a concentrations between the 2 sampling periods. However, chl a decreased significantly from south to north (spatial autocorrelation, $\mathrm{p}<0.05$ ) in early autumn. The POC:PON ratio ranged from 5.7 to 10.4 (Table 1) and was close to the value of 7.7 (g:g) reported by Redfield et al. (1963).

\section{Nitrogen uptake rates}

Total nitrate uptake ranged from 0.02 to $1.51 \mathrm{mmol} \mathrm{N}$ $\mathrm{m}^{-2} \mathrm{~h}^{-1}$ (Fig. 3A) with a mean value of $0.32 \mathrm{mmol}$ $\mathrm{N} \mathrm{m}^{-2} \mathrm{~h}^{-1}$. Ammonium uptake rates varied between 0.03 and $1.18 \mathrm{mmol} \mathrm{N} \mathrm{m}^{-2} \mathrm{~h}^{-1}$ (mean $0.26 \mathrm{mmol} \mathrm{N} \mathrm{m}{ }^{-2}$ $\mathrm{h}^{-1}$; Fig. 3B), while the maximum urea uptake was lower, ranging from $<0.01$ to 0.30 (mean $0.11 \mathrm{mmol}$ $\mathrm{N} \mathrm{m}^{-2} \mathrm{~h}^{-1}$; Fig. 3C). Over the entire region and for both legs of the mission, nitrate and ammonium were taken up at comparable rates (Fig. 3A,B), but only nitrate uptake rates were significantly higher $(p<0.05)$ than urea uptake rates.

Between the 2 sampling periods, uptake rates of the 3 nitrogenous nutrients decreased significantly $(p<$ 0.05 ) by $\sim 75 \%$ (Table 2 ). Over the entire study period, uptake rates were positively correlated with the aver- age irradiance in the euphotic zone (for $\rho \mathrm{NO}_{3}^{-}: \tau=0.58$, $\mathrm{p}<0.001 ; \rho \mathrm{NH}_{4}^{+}: \tau=0.44, \mathrm{p}<0.05$; $\rho$ Urea: $\tau=0.37, \mathrm{p}<$ $0.05)$. Nitrate uptake was also negatively correlated with the depth of the euphotic zone $(\tau=-0.36, p<$ $0.05)$. Ammonium and urea uptake were both positively correlated with mean water temperature in the euphotic zone $(t=0.36$ and 0.38 , respectively, $\mathrm{p}<0.05)$.

In late summer, there was no significant spatial pattern in any of the nitrogen uptake rates (Fig. 3). However, in early autumn, when nitrate uptake was correlated with chl a $(\tau=0.49, \mathrm{p}<0.05)$, nitrate uptake rates at Stns 2 and $6\left(>78^{\circ} \mathrm{N}\right)$ were significantly higher than at the southern stations ( $p<0.05$; Fig. 3A). South of $78^{\circ} \mathrm{N}$, nitrate uptake rates were significantly higher near the Greenland coast than along the Canadian coast. Ammonium and urea uptake rates did not exhibit this east-west trend in early autumn (Fig. 3B,C).

\section{f-ratios and new production}

The fraction of nitrate uptake compared with the sum of nitrate, ammonium and urea uptake is used to estimate the $f$-ratio, and new production can be estimated by multiplying this ratio by primary production (Eppley \& Peterson 1979). Even though nitrogen 
uptake decreased significantly between late summer and early autumn 1999, no seasonal trend was observed for the ratio of nitrate uptake to total nitrogen uptake, which ranged from 0.10 to 0.70 and had a mean value of 0.39 (Table 2). This fraction equaled or exceeded 0.50 at the northernmost stations (N2/N3) and at stations on the Greenland side (E2, S2 and 76). These values reflected the entire nitrogenous nutrition of the planktonic community, i.e. of both autotrophic and heterotrophic microorganisms.

During the same study, Fouilland et al. (2007) used metabolic inhibitors to determine the partitioning in the uptake of nitrate, ammonium and urea between heterotrophic bacteria and phytoplankton in the surface waters at 4 stations in the NOW (Stns 38, 43, 50 and near 76). These authors used ${ }^{15} \mathrm{~N}$-labelled nitrogen and specific metabolic inhibitors of prokaryote (streptomycin: SM) and eukaryote (cycloheximide: CHI) nitrogen metabolism. These inhibitors were added $1 \mathrm{~h}$ before ${ }^{15} \mathrm{~N}$ incubations at a final concentration of $25 \mathrm{mg} \mathrm{l}^{-1}$. The rates of nitrogen uptake with metabolic inhibitors were compared with those from uninhibited controls. A positive 1:1 ratio was obtained between the sum of uptake rates measured with individual additions of $\mathrm{CHI}$ and SM and the nitrogen uptake rates measured without metabolic inhibitors (Fouilland et al. 2007). This suggests a high specificity of the different metabolic inhibitors used. Fouilland et al. (2007) found that, on average, phytoplankton accounted for 31 and $85 \%$ of the total uptake of ammonium and urea, respectively, in late September. They also showed that the phytoplankton and bacterial contribution to total nitrate uptake depended on chl a concentration (phytoplankton biomass). They estimated that phytoplankton accounted for an average of $26 \%$ of the total community nitrate uptake when chl a concentration was equal to or lower than $2 \mathrm{mg} \mathrm{m}^{-3}$. This average increased to $64 \%$ when the concentrations were greater.

To improve the new production estimate, we computed a corrected atomic $f$-ratio $\left(f\right.$-ratio $\left._{\text {corr }}\right)$, which takes into account only the fraction of the dissolved nitrogen (i.e. nitrate, ammonium and urea) taken up by phytoplankton. We assumed that, during our study, phytoplankton accounted for 31 and $85 \%$ of the total planktonic uptake of ammonium and urea, respectively, and for 26 or $64 \%$ of total planktonic uptake of nitrate (Fouilland et al. 2007). At stations where phytoplankton accounted for only $26 \%$ of the total nitrate uptake (chl $a \leq 2 \mathrm{mg} \mathrm{m}^{-3}$ ), $f$-ratios corr $_{\text {ranged from } 0.06}$ to 0.49 (mean 0.24 ) in late summer and from 0.06 to 0.39 (mean 0.24 ) in early autumn. At the other stations (chl a $>2 \mathrm{mg} \mathrm{m}^{-3}$ ), $f$-ratios corr $_{\text {were higher, ranging }}$ from 0.14 to 0.70 (mean 0.41 ) in late summer and from
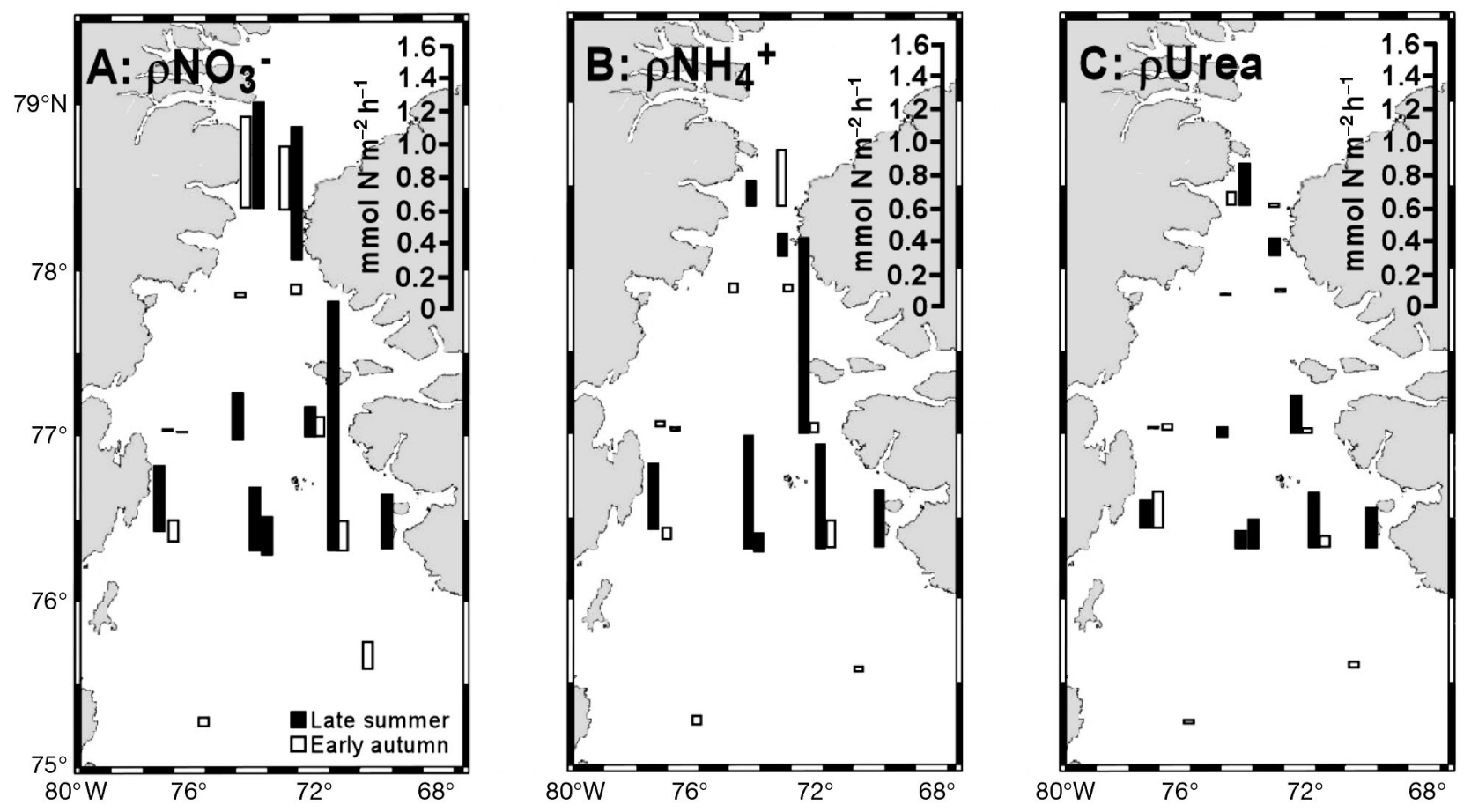

Fig. 3. Spatial variations in absolute uptake rates of (A) nitrate $\left(\rho \mathrm{NO}_{3}{ }^{-}\right)$, (B) ammonium $\left(\rho \mathrm{NH}_{4}{ }^{+}\right)$and (C) urea ( $\rho$ Urea) in the NOW in late summer (black bars) and early autumn (open bars). Values were depth-integrated from the surface to $0.1 \%$ of surface irradiance 
0.12 to 0.61 (mean 0.42 ) in early autumn. These lower and higher mean values are reported for both sampling periods (Table 2). The $f$-ratios corr $_{\text {exceeded } 0.50}$ at northernmost stations E2 and 2 only when assuming that the phytoplankton dominated the total nitrate uptake. There was no significant decrease between late summer and early autumn and, when all the data were combined, the averaged $f$-ratio $_{\text {corr }}$ range was 0.24 to 0.41 .

New production was obtained by multiplying the $f$ ratio $_{\text {corr }}$ with the particulate primary production estimated from the ${ }^{14} \mathrm{C}$-assimilation (Klein et al. 2002); however, values were integrated down to $0.1 \%$ PAR in our study. Using the averaged $f$-ratios corr $_{\text {range, new }}$ production was estimated to be 203 to $346 \mathrm{mg} \mathrm{C} \mathrm{m}^{-2}$ $\mathrm{d}^{-1}$ in late summer and 85 to $149 \mathrm{mg} \mathrm{C} \mathrm{m}^{-2} \mathrm{~d}^{-1}$ in early autumn (Table 2 ). Using the averaged $f$-ratio corr $_{\text {range }}$ of 0.24 to 0.41 , the weighted average of new production over the entire period was 132 to $228 \mathrm{mg} \mathrm{C} \mathrm{m}^{-2} \mathrm{~d}^{-1}$. For the whole sampling period (35 d), particulate primary production was $19.3 \mathrm{~g} \mathrm{C} \mathrm{m}^{-2}$, while new production ranged between 4.6 and $8.0 \mathrm{~g} \mathrm{C} \mathrm{m}^{-2}$.

\section{DISCUSSION}

This study provides estimates of the nitrogenous nutrition of plankton at the end of the phytoplankton's productive season, and proposes an explanation for the decline of the autumn bloom in the NOW. Our analysis of environmental factors suggests that nitrogenous uptake by plankton was influenced spatially by the nitrate supply and seasonally by incident irradiance. Using data from the present study together with relevant published data, we compared various estimates of new and export production. To our knowledge, the combination of our results with those from a previous cruise in the same geographical area provides a unique and realistic annual estimate of the new and export production in a high-latitude ecosystem.

\section{Nitrogen uptake in the NOW during late summer-early autumn}

A noteworthy result of this study was the rapid 3-fold decrease in nitrogen uptake rates during the summerautumn transition period without any significant decrease in phytoplankton standing stock (i.e. PON and chl $a_{i}$ Table 1). The considerable reduction in the uptake rates of each nitrogenous nutrient followed the decrease in underwater irradiance. Polar regions are characterized by extreme light regimes and a strong decrease in incident irradiance from summer to autumn. Such a seasonal decline was responsible for
Table 2. Nitrogenous uptake and primary production in the NOW in 1999 in late summer (Leg 1) and early autumn (Leg 2). Mean values (range in parentheses) of absolute uptake rates of nitrate $\left(\rho \mathrm{NO}_{3}{ }^{-}\right)$, ammonium $\left(\rho \mathrm{NH}_{4}{ }^{+}\right)$, urea ( $\rho$ Urea), total nitrogen $\left(\rho \mathrm{N}\right.$, sum of $\rho \mathrm{NO}_{3}{ }^{-}, \rho \mathrm{NH}_{4}{ }^{+}$and $\rho$ Urea all in mmol $\mathrm{N} \mathrm{m}^{-1} \mathrm{~h}^{-1}$ ) and atomic $f$-ratio (dimensionless); atomic $f$-ratio corr $_{\text {range when phytoplankton accounted for } 31}$ and $85 \%$ of total planktonic uptake of $\mathrm{NH}_{4}{ }^{+}$and urea, respectively, and 26 and $64 \%$ of total planktonic uptake of $\mathrm{NO}_{3}{ }^{-}$ (Fouilland et al. 2007); and corresponding Mann-Whitney $U$-test or Student's $t$-test results for significant differences $(>$ or $<$ ) between Legs 1 and 2. Also given are mean or range values for particulate primary production, total primary production (particulate + dissolved), new production and total new production (particulate + dissolved) (all $\mathrm{mg} \mathrm{C} \mathrm{m}^{-2} \mathrm{~d}^{-1}$ ) according to the $f$-ratio ${ }_{\text {corr }}$ range. Rates calculated from the weighted average over the entire period are also presented. ${ }^{*}: \mathrm{p}<0.05 i^{* *}: \mathrm{p}<0.001$

\begin{tabular}{|c|c|c|c|}
\hline Variable & Late summer & & Early autumn \\
\hline $\mathrm{\rho NO}_{3}^{-}$ & $\begin{array}{c}0.53 \\
(0.19-1.51)\end{array}$ & $>^{*}$ & $\begin{array}{c}0.16 \\
(0.02-0.56)\end{array}$ \\
\hline$\rho \mathrm{NH}_{4}^{+}$ & $\begin{array}{c}0.46 \\
(0.12-1.18)\end{array}$ & $>^{*}$ & $\begin{array}{c}0.10 \\
(0.03-0.35)\end{array}$ \\
\hline purea & $\begin{array}{c}0.18 \\
(0.06-0.31)\end{array}$ & $>^{* *}$ & $\begin{array}{c}0.05 \\
(0.01-0.20)\end{array}$ \\
\hline$\rho N$ & 1.34 & $>^{* *}$ & 0.36 \\
\hline$f$-ratio & $\begin{array}{c}0.39 \\
(0.10-0.70)\end{array}$ & $=$ & $\begin{array}{c}0.38 \\
(0.13-0.61)\end{array}$ \\
\hline$f$-ratio $_{\text {corr }}$ range & $0.24-0.41$ & $=$ & $0.24-0.42$ \\
\hline Particulate primary prod ${ }^{\mathrm{a}}$. & 845 & & 354 \\
\hline Total primary production ${ }^{\mathrm{a}}$ & 1781 & & 634 \\
\hline New production & $203-346$ & & $85-149$ \\
\hline Total new production & $427-730$ & & $152-266$ \\
\hline \multicolumn{4}{|c|}{ Weighted average over the entire period } \\
\hline \multirow{4}{*}{$\begin{array}{l}\text { Particulate primary prod. } \\
\text { Total primary production } \\
\text { New production } \\
\text { Total new production }\end{array}$} & \\
\hline & \multicolumn{3}{|c|}{1093} \\
\hline & \multicolumn{3}{|c|}{$132-228$} \\
\hline & \multicolumn{3}{|c|}{$262-452$} \\
\hline
\end{tabular}

the reduction in the primary producer biomass and production from the spring bloom to the autumnal period in the NOW (Klein et al. 2002). Nitrogen uptake rates in the Arctic Ocean have been shown to decrease with irradiance, especially for urea and nitrate (Smith \& Harrison 1991, Tremblay et al. 2006). Light availability was likely a key factor explaining the decline in productivity of the autumn bloom. The limiting effect of light on phytoplankton growth probably did not apply to most of the heterotrophic bacteria; this probably explains why they contributed substantially (between 32 and $95 \%$ ) to the total nitrate uptake at the end of the bloom (Fouilland et al. 2007). This suggests a decoupling of photosynthetic from heterotrophic bacterial production as winter conditions of low irradiance and nutrient shortage set in.

Three factors were responsible for the reduction in irradiance in the euphotic zone during our study 
period. First, the Baffin Bay area was predominantly ice-free during August and September and there was hardly any ice at the sampling stations during Leg 1. However, in early autumn, heavy ice was present along the Canadian coast due to advection from the north through Nares Strait (Barber et al. 2001). Second, seasonal thickening of the cloud cover (Table 1) reduced incident light. Third, during sampling, seasonal changes in the declination of the earth and the solar zenith angle caused drastic decreases in incident irradiance on an hourly and daily basis (e.g. Brock 1981). Mean irradiance in the euphotic zone decreased to values of $\sim 0.9 \mathrm{~mol}$ photons $\mathrm{m}^{-2} \mathrm{~d}^{-1}$. This value is lower than the average irradiance (PAR) of 1.3 mol photons $\mathrm{m}^{-2} \mathrm{~d}^{-1}$ that is critical for the initiation of net phytoplankton growth throughout much of the North Atlantic (Siegel et al. 2002). The depth of the mixed layer was unlikely to have any important control on underwater light availability for phytoplankton during our study. The shallow $(<30 \mathrm{~m})$ mixed-layer depth was relatively uniform in space and time, and it was always within the euphotic zone. Thus, the decline in nitrogen uptake rates by the end of September could be due to low mean irradiance in the euphotic zone that did not support a highly active phytoplankton community.

Our results showed a considerable utilization of regenerated nitrogen by the planktonic community during late summer-early autumn, despite the fact that the concentrations of regenerated forms (ammonium and urea) in the euphotic zone were 10 times lower than those of new nitrogen (nitrate). A similar situation, where most of the primary production was sustained by regenerated nitrogen, occurred during late summer in northern Baffin Bay, in the NEW Polynya, and in the deep Canada Basin of the Arctic Ocean, but nitrate in these systems was nearly depleted in the surface mixed layer (Harrison et al. 1985, Daly et al. 1999, Lee \& Whitledge 2005). The most likely explanation is that even though nitrate was available in the NOW, the community had shifted to a nitrogen regime based on regenerated forms because the assimilation of these forms requires less energy than nitrate assimilation (Dortch 1990). Our work also corroborates other studies suggesting that urea can be an important source of nitrogen for phytoplankton growth in Arctic (Harrison et al. 1985, Daly et al. 1999) and Antarctic waters (Sambrotto \& Mace 2000). Low $\mathrm{N}: \mathrm{Si}(\mathrm{OH})_{4}$ ratios $(<1.1)$ were consistent with results from earlier in the season (Tremblay et al. 2006) and were indicative of nitrate depletion throughout most the region. Nevertheless, spatial patterns in nitrate concentration also appeared.

At the beginning of the phytoplankton growth season in April, nitrate concentrations in the upper $100 \mathrm{~m}$ of the water column were as high as 12 to $14 \mathrm{mmol} \mathrm{m}^{-3}$, and decreased to $6 \mathrm{mmol} \mathrm{m}^{-3}$ by mid-July (Tremblay et al. 2002a). While minor nitrate depletion was observed in the north along the Canadian coast in June, it was severely reduced in this region by July (Tremblay et al. 2002a). This trend was still noticeable in early autumn, suggesting that nitrate depletion continued through August and September in the northwestern part of the NOW. This nitrate depletion in the southward-flowing Arctic waters (cf. Melling et al. 2001) might be due to the phytoplankton bloom in Kane Basin, which is clearly visible on SeaWiFS images obtained from August 1999 (Booth et al. 2002). In addition to the reduction in irradiance, low nitrate availability was likely a second factor explaining the end of the main phytoplankton bloom along the Canadian coast in autumn 1999.

Interestingly, spatial variations in temperature, salinity and nitrate supply in the NOW did not directly affect the total uptake rate of nitrogen but rather had an impact on the relative contribution of the different nitrogen forms used. During the second part of the sampling period, 2 station clusters were differentiated on the basis of the nitrate contribution to total nitrogen uptake ( $f$-ratio) and the chl $a_{\mathrm{L}}$ : chl a ratio. The clusters were located in water masses of distinct physicochemical properties. The first group included stations of the northwestern sector of the NOW (Stns 2, 15, 31, 32 and 45), where Arctic waters were relatively fresh $(30.2<S<32.2)$ and cool $\left(T-1.0^{\circ} \mathrm{C}\right.$; Table 3$)$. The second group (Stns 6, 18, 40,54, 66 and 76) was located in the relatively salty $(32.3<S<33.2)$ and warm $(T>$ $-0.5^{\circ} \mathrm{C}$ ) nitrate-rich Atlantic water of the southeastern sector along the Greenland coast. Correlation analysis indicated that the main modulator of nitrogen uptake in early autumn was the availability of nitrate in the euphotic zone, with no significant effect of temperature. Atlantic-derived waters supplied new nitrogen to the Greenland area of the NOW, which resulted in relatively high (not corrected) f-ratios (0.52) compared with the Canadian region $(0.27)$. This contrasts with our initial hypothesis and with the observations made by Sambrotto \& Mace (2000) of a positive relationship between temperature and ammonium uptake in the warmest waters of the Antarctic Polar Front region in summer and autumn, where ammonium uptake was higher than nitrate uptake, possibly due to increased microbial production of regenerated nutrients. The observed $f$-ratios exceeding 0.50 at northernmost Stn N2/N3 may be explained by a supply of nitrate through Smith Sound in the northern sector of the NOW from Pacific waters (Tremblay et al. 2002b). Nitrate availability regulated the variation in the relative uptake of nitrate, but mainly over spatial scales and at the end of the sampling period. 


\section{New production during autumn}

The nitrogenous nutrition of phytoplankton provides insights into the potential fate of primary production and can be used to estimate the amount that can be exported from the euphotic zone and the remaining portion that will be consumed where it was produced. The portion of primary production derived from the reduced nitrogen and excreted by heterotrophic organisms within the euphotic zone, especially ammonium and urea, is referred to as regenerated production, whereas the portion driven by externally supplied nitrogen, mostly nitrate from deep waters, is called new production (Dugdale \& Goering 1967). In systems that are nitrogenlimited — such as the NOW (Tremblay et al. 2006) — and at steady state, export production is considered to be stoichiometrically equivalent to new production and to the injection of allochthonous nitrogen into the euphotic zone (Eppley \& Peterson 1979). The steady state implies a closed system in which inputs and outputs are balanced, a situation that is believed to be possible over large areas (Eppley \& Peterson 1979) and/or time scales (6 mo or more; Dauchez et al. 1996). From this concept, the $f$-ratio was defined as the ratio of new to total production (Eppley \& Peterson 1979). Different approaches can be used to quantify new production, and most of them are based on the assimilation of nitrate by phytoplankton measured by ${ }^{15} \mathrm{~N}$-labeling techniques (Dugdale \& Goering 1967), or from the disappearance of nitrate over time (Smith et al. 1991). Therefore, we computed different new production estimates for the late summer-early autumn expedition of 1999 and compared them with direct measurements of downward export fluxes of particles reported in the literature for the same area and period.

Classically, new production is estimated from the product of the $f$-ratio and primary production, assuming that dissolved inorganic nitrogen is taken up only by phytoplankton (Dugdale \& Goering 1967). Even though bacterial nitrogen uptake is widely recognized to impact new production estimates (Kirchman et al. 1992, Kirchman 2000), few new production values actually remove the bacterial contribution to nitrogen uptake. Kirchman et al. (1992) redefined new production as the carbon production from the uptake of nitrate by all organisms and stated that there is no need to correct values (1) when primary production includes the dissolved fraction and (2) if new production is computed over a sufficiently long time scale to include bacteria in export fluxes. Nonetheless, these authors agreed that nitrate uptake by bacteria would lead to time lags between primary production and new production, and thus potential export, because of the small cell size of bacteria. Since bacteria could account for up to $95 \%$ of the total nitrate uptake in the NOW (Fouilland et al. 2007) and this study covered only 35 d, the correction for heterotrophic nitrogen uptake was needed. Consequently, we corrected our $f$-ratio $\left(f\right.$-ratio $\left._{\text {corr }}\right)$ by estimating the fraction of the nitrogen uptake that was attributed to bacteria. The corresponding range of new production estimates based on these corrected $f$-ratios is 132 to $228 \mathrm{mg} \mathrm{C} \mathrm{m}^{-2} \mathrm{~d}^{-1}$ (Tables $2 \& 4$ ).

The above calculation was based on particulate carbon production and did not consider the production of dissolved organic carbon (DOC) by phytoplankton. On average, the primary production released as DOC represented $\sim 44 \%$ of the total primary production from April to September 1999 in the NOW (Klein et al. 2002). Moreover, it was shown that some DOC accumulated in the surface mixed layer during late summer-early autumn and was potentially exported (Miller et al. 2002). Thus, by neglecting dissolved primary production, new production may be considerably underestimated. To take into account the potential export of dissolved organic matter, and hence give accurate estimates of new production, the $f$-ratio ${ }_{\text {corr }}$ must be multiplied by the sum of both particulate and dissolved primary production. New production computed as such, hereafter called total new production, varied between 262 and $452 \mathrm{mg} \mathrm{C} \mathrm{m}^{-2} \mathrm{~d}^{-1}$ (Tables 2 \& 4). Over a $35 \mathrm{~d}$ period, this corresponds to between 9 and $21 \mathrm{~g}$ $\mathrm{m}^{-2}$ of carbon that can potentially be exported. This should be considered as an upper limit to new production for the NOW area during a late summer bloom.

New production can be estimated from the removal of nitrate from the euphotic zone (Smith et al. 1991) when assuming that (1) the decrease in nitrate concentration is primarily due to biological uptake rather than advection, (2) diffusive loss and supply of nitrate are negligible compared with the rate of removal, and (3) regenerative processes (particularly the production of nitrate by nitrification) are slow relative to 
removal processes. Even though a slight increase was observed north of $77^{\circ} \mathrm{N}$, the overall nitrate concentration decreased in the NOW system; in contrast, PON concentration (biomass) remained constant between late summer and early autumn 1999 (Table 1). This indicates that the PON produced from the uptake of nitrate in the euphotic zone was exported to deeper waters or towards heterotrophic consumers. In order to estimate this new production rate, the difference in nitrate concentration in the euphotic zone (in mmol $\mathrm{N}$ $\mathrm{m}^{-2}$ ) between the 2 sampling periods was converted into carbon production (in $\mathrm{mg} \mathrm{C} \mathrm{m}^{-2}$ ) using the atomic $\mathrm{C}: \mathrm{N}$ ratio for plankton. The result was then divided by the number of days between the mid-points of Leg 1 and Leg 2. As previously done in the NEW Polynya (Smith et al. 1997, Daly et al. 1999), the atomic C:N ratio of 7.86 that was used for conversion was determined with a Model II regression $(y=7.86 x+1.06, \mathrm{n}=$ $140, r=0.85, p<0.001$ ) between POC and PON concentrations at the beginning of the ${ }^{15} \mathrm{~N}$ incubations, taking into consideration that both variables contained errors (Sokal \& Rohlf 1981). The estimated new production from nitrate depletion was $317 \mathrm{mg} \mathrm{C} \mathrm{m}^{-2} \mathrm{~d}^{-1}$ (i.e. $\left.[(124-67) \times 7.86 \times 12] \times 17^{-1}\right)$, which was within the previously calculated interval of 262 to $452 \mathrm{mg} \mathrm{C}$ $\mathrm{m}^{-2} \mathrm{~d}^{-1}$ that included both dissolved and particulate forms of new production (Table 4). Despite this agreement, long-term nitrate removal reflected the entire community's nitrate uptake, and thus included uptake by bacteria. On a monthly time scale such as our sampling period, this could lead to an overestimation of new production. The C:N ratio of plankton was used in the calculation, but it might be appropriate to correct it for the bacteria's C:N ratio of 4.5 (Lee \& Furhman 1987) because of the contribution of bacteria nitrate uptake to the total community uptake.

Our calculations indicated that new production in the NOW during late summer-early autumn was quite high (132 to $596 \mathrm{mg} \mathrm{C} \mathrm{m}^{-2} \mathrm{~d}^{-1}$ ). Total new production exceeded the value of $250 \mathrm{mg} \mathrm{C} \mathrm{m}^{-2} \mathrm{~d}^{-1}$ obtained from nitrate uptake in March in the Weddell Sea (Southern Ocean; Smith \& Nelson 1990) and greatly exceeded the value of $9 \mathrm{mg} \mathrm{C} \mathrm{m}^{-2} \mathrm{~d}^{-1}$ rate estimated in the deep Canada Basin in late summer using a $\mathrm{NO}_{3}{ }^{-}$uptake rate of $1.96 \mathrm{mg} \mathrm{N} \mathrm{m}^{-2} \mathrm{~d}^{-1}$ and a C:N ratio of 4.4 (Lee \& Withledge 2005). In comparison, new production estimates during the NEW Polynya Study from late May to mid-August ranged from $\sim 250$ to $470 \mathrm{mg} \mathrm{C} \mathrm{m}^{-2} \mathrm{~d}^{-1}$, depending on the year and the calculation method (Smith et al. 1997, Daly et al. 1999).

Overestimation (33 to $45 \%$ ) of ammonium and urea uptake rates induced by ${ }^{15} \mathrm{~N}$ enrichment had impacts on the $f$-ratio and the new production estimation. When values of ammonium and urea uptake are reduced by $45 \%$,

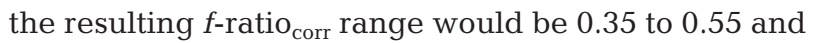
new production for the whole sampling period would be $30 \%$ higher on average than presented in Table 1. Nevertheless, our results still reflected the importance of regenerated nitrogen in phytoplankton nutrition and yet showed that the NOW was a productive system at the end of the growing season.

\section{Export production during late summer and autumn}

Export production, which is assumed to be equivalent to new production in a steady-state system (Eppley \& Peterson 1979), can also be estimated from the size structure of the phytoplankton community. Using this approach, Klein et al. (2002) estimated the potential export of POC from the euphotic zone to be 395 and $131 \mathrm{mg} \mathrm{C} \mathrm{m}^{-2} \mathrm{~d}^{-1}$ in late summer and early autumn 1999, respectively (Table 4 ). For the entire sampling period, the weighted average rate was $237 \mathrm{mg} \mathrm{C} \mathrm{m}^{-2} \mathrm{~d}^{-1}$, a value very close to the top end of the classical new production range. Export production can also be assessed from direct measurement of sinking particle flux using shortterm free-drifting sediment traps. Between 27 August and 1 October 1999, the mean sinking flux of POC measured at $150 \mathrm{~m}$ was $142 \mathrm{mg} \mathrm{C} \mathrm{m}^{-2} \mathrm{~d}^{-1}$ (Caron et al. 2004). This value is at the lower end of the classical new production estimates and is also similar to potential export based on phytoplankton community size structure (Table 4). Finally, export production can be derived

Table 4. Comparison of new and export production $\left(\mathrm{mg} \mathrm{C} \mathrm{m}^{-2} \mathrm{~d}^{-1}\right)$ in the NOW in late summer, early autumn, and for the entire sampling period (weighted average according to no. of days of each leg). PP: primary production; PPtot: total primary production (dissolved + particulate); $\rho \mathrm{NO}_{3}^{-}$: hourly nitrate uptake; D: day length within $24 \mathrm{~h}$; size structure: phytoplankton size structure (cf. Klein et al. 2002); FST: free-drifting short-term sediment traps deployed at $150 \mathrm{~m}$ (Caron et al. 2004); ${ }^{234}$ Th: patterns of ${ }^{234} \mathrm{Th}:{ }^{238} \mathrm{U}$ ratio disequilibrium at $100 \mathrm{~m}$ (Amiel et al. 2002); nd: no data available

\begin{tabular}{|c|c|c|c|c|c|c|c|}
\hline \multirow{2}{*}{ Period } & \multicolumn{3}{|c|}{ New production } & \multicolumn{4}{|c|}{ Export production } \\
\hline & $\begin{array}{c}\text { Classical } \\
{ }^{14} \mathrm{C} \mathrm{PP} \times f \text {-ratio }_{\text {corr }}\end{array}$ & $\begin{array}{c}\text { Total } \\
\text { PPtot } \times f \text {-ratio } \\
\text { corr }\end{array}$ & $\begin{array}{c}{ }^{15} \mathrm{NO}_{3}{ }^{-} \text {uptake } \\
\mathrm{NNO}_{3}{ }^{-} \times \mathrm{C}: \mathrm{N} \times \mathrm{D}\end{array}$ & $\mathrm{NO}_{3}{ }^{-}$removal & Size structure & FST & ${ }^{234} \mathrm{Th}$ \\
\hline Late summer & $203-346$ & $427-730$ & 934 & nd & 395 & nd & nd \\
\hline Early autumn & $85-145$ & $152-266$ & 371 & nd & 131 & nd & nd \\
\hline Entire period $(35 \mathrm{~d}$ & $132-228$ & $262-452$ & 596 & 317 & 237 & 142 & 104 \\
\hline
\end{tabular}


from the upper water column deficits of ${ }^{234} \mathrm{Th}$ relative to ${ }^{238} \mathrm{U}$. This ratio is then multiplied by the POC: ${ }^{234} \mathrm{Th}$ ratio of sinking particles (Buesseler et al. 1992). Using the latter method in August - September 1999 at Stns N1/3 (near Stn N2/N3 of the present study), E2, E1, D2, S5, S4 and S2, Amiel et al. (2002) estimated the POC flux at $100 \mathrm{~m}$ to be $104 \mathrm{mg} \mathrm{C} \mathrm{m}^{-2} \mathrm{~d}^{-1}$, a value slightly lower than 2 previous estimates of export production (Table 4 ).

New production estimated from particulate primary production and the $f$-ratio ${ }_{\text {corr }}\left(132\right.$ to $228 \mathrm{mg} \mathrm{C} \mathrm{m}^{-2} \mathrm{~d}^{-1}$ ) matched the export production determined from community size structure, particle interceptor traps and the ${ }^{234} \mathrm{Th}$ method. This agreement might have arisen because new production reflected only the particulate downward sinking of organic carbon in the NOW over our sampling period. Thus, in late summer-early autumn, the flux of POC out of the euphotic zone was in the range of 104 to $237 \mathrm{mg} \mathrm{C} \mathrm{m}^{-2} \mathrm{~d}^{-1}$. However, this range did not include downward mixing of DOC or dissolved organic nitrogen (DON) produced in the euphotic zone, even though this downward mixing may be an important process for the export of surface carbon and nitrogen production (Carlson et al. 1994).

\section{Annual new production}

To obtain an annual estimate of new production in the NOW, we combined the new production values reported from April to July 1998 (Tremblay et al. 2002b), which were not corrected for bacterial nitrogen uptake, and estimates of new production for autumn that were also not corrected for bacterial nitrogen uptake. This estimate of new production was calculated by converting the daily molar uptake rate of nitrate into carbon equivalents $\left(\mathrm{mg} \mathrm{C} \mathrm{m}^{-2} \mathrm{~d}^{-1}\right)$ with the $\mathrm{C}: \mathrm{N}$ atomic ratio of plankton previously determined and the atomic weight of carbon. This calculation gives a value of $596 \mathrm{mg} \mathrm{C} \mathrm{m}^{-2} \mathrm{~d}^{-1}$ for autumn. This value completes the data set obtained for April, May, June and July of 1998 with new production values of 440, 1720, 1430 and $690 \mathrm{mg} \mathrm{C} \mathrm{m} \mathrm{d}^{-1}$, respectively (Tremblay et al. 2002b). All these values may be overestimated because no corrections were made for the bacterial nitrogen uptake, which requires appropriate $\mathrm{C}: \mathrm{N}$ ratio allocation. However, because the time scale shifts to an annual basis, we assumed that this period was long enough to average out the imbalance between primary and bacterial production (Kirchman et al. 1992). Since data were collected during cruises conducted in 2 subsequent years, this should be considered as a seasonal composite of an April-September cycle. We recognize that interannual and spatial variations of physical and meteorological conditions (e.g. ice cover, wind and currents) likely influenced the pre- cise timing, distribution and intensity of the phytoplankton bloom. Nevertheless, this composite annual cycle, presently the best possible for this region, is a reasonable representation of the general temporal trends and regional variations in the NOW.

With this extended data set, the annual new production of the NOW area was estimated to be 143 to $152 \mathrm{~g}$ $\mathrm{C} \mathrm{m}^{-2}$. This high value represents $\sim 60 \%$ of the total annual production in the NOW $\left(251 \mathrm{~g} \mathrm{C} \mathrm{m}^{-2}\right.$; Klein et al. 2002), which is among the highest proportion of new production reported for a polar area. For instance, nitrate-based new production in the NEW Polynya is 3 times lower, amounting to $43 \mathrm{~g} \mathrm{C} \mathrm{m}^{-2} \mathrm{yr}^{-1}$ when assuming a productive period of $120 \mathrm{~d}$ (Smith et al. 1997). New production at the ice edge of the Antarctic Polar Front region $\left(40 \mathrm{~g} \mathrm{C} \mathrm{m}^{-2} \mathrm{yr}^{-1}\right.$; Sambrotto \& Mace 2000) is also considerably lower. These results clearly indicate that the NOW area remained quite productive, even at the very end of the production season, and that the system was able to either support the rich Arctic fauna in surface waters or to export carbon towards the sediments or adjacent regions.

Our study presented $f$-ratios that were corrected for nitrogen uptake by heterotrophic bacteria to obtain more accurate estimates of both new and regenerated production. As typically observed at the end of the production season, phytoplankton production during this period was mainly based on regenerated nitrogen, but daily rates of new production were also significant. Despite large differences in the methodologies used to estimate new and export production in the study region, particulate downward fluxes of carbon near the end of season were in the relatively narrow range of 104 to $237 \mathrm{mg} \mathrm{C} \mathrm{m}^{-2} \mathrm{~d}^{-1}$. When the dissolved form of organic carbon production was included, new production doubled to between 262 and $596 \mathrm{mg} \mathrm{C} \mathrm{m}^{-2} \mathrm{~d}^{-1}$ (Table 4), which illustrates that dissolved forms can be significant and need to be considered in future research on new and export production.

Acknowledgements. This study was funded by the Natural Sciences and Engineering Research Council (NSERC) of Canada. Extensive logistical support was provided by the Polar Continental Shelf Project (Energy, Mines and Resources Canada). M.È.G. received post-graduate scholarships from NSERC, the Fondation de l'UQAR (bourse Estelle-Laberge) and the Institut des sciences de la mer de Rimouski (ISMER), and financial support from Indian and Northern Affairs Canada for fieldwork. We thank Captain R. Dubois and the crew of CCGS 'Pierre-Radisson' for their outstanding help; R. Beret and B. LeBlanc for field assistance; L. McLaughlin and M. Dubé for nutrient analyses; G. St. Jean (G. G. Hatch Isotope Laboratories) for stable isotope analyses; Y. Gratton for physical oceanographic data; and M. Levasseur, L. Legendre, D. Mueller, D. Antoniades, Z. Mei, C. Lovejoy and 3 anonymous referees for useful comments on the manuscript. This is a contribution to the research programs of the International North Water Polynya Study, ISMER, and Québec-Océan. 


\section{LITERATURE CITED}

Amiel D, Cochran JK, Hirschberg DJ $(2002){ }^{234} \mathrm{Th} /{ }^{238} \mathrm{U}$ disequilibrium as an indicator of the seasonal export flux of particulate organic carbon in the North Water. Deep-Sea Res II 49:5191-5209

Barber DG, Marsden R, Minett P, Ingram G, Fortier L (2001) Physical processes within the North Water (NOW) Polynya. Atmos-Ocean 39:163-166

Booth B, Larouche P, Bélanger S, Klein B, Amiel D, Mei ZP (2002) Dynamics of Chaetoceros socialis blooms in the North Water. Deep-Sea Res II 49:5003-5025

Brock TD (1981) Calculating solar radiation for ecological studies. Ecol Model 14:1-19

Buesseler KO, Bacon MP, Cochran JK, Livingston HD (1992) Carbon and nitrogen export during the JGOFS North Atlantic Bloom Experiment estimated from ${ }^{234} \mathrm{Th}:{ }^{238} \mathrm{U}$ disequilibria. Deep-Sea Res 39:1115-1137

Carlson CA, Ducklow HW, Michaels AF (1994) Annual flux of dissolved organic carbon from the euphotic zone in the northwestern Sargasso Sea. Nature 371:405-408

Caron G, Michel C, Gosselin M (2004) Seasonal contributions of phytoplankton and fecal pellets to the organic carbon sinking flux in the North Water (northern Baffin Bay). Mar Ecol Prog Ser 283:1-13

Daly KL, Wallace DWR, Smith WO Jr, Skoog A, Lara R, Gosselin M, Falck E, Yager PL (1999) Non-Redfield carbon and nitrogen cycling in the Arctic: effects of ecosystem structure and dynamics. J Geophys Res C 104:3185-3199

Dauchez S, Legendre L, Fortier L, Levasseur M (1996) New production and production of large phytoplankton $(>5 \mu \mathrm{m})$ on the Scotian Shelf (NW Atlantic). Mar Ecol Prog Ser 135:215-222

Dortch Q (1990) The interaction between ammonium and nitrate uptake in phytoplankton. Mar Ecol Prog Ser 61: 183-201

Dugdale RC, Goering JJ (1967) Uptake of new and regenerated forms of nitrogen in primary productivity. Limnol Oceanogr 12:196-206

Dugdale RC, Wilkerson FP (1986) The use of ${ }^{15} \mathrm{~N}$ to measure nitrogen uptake in eutrophic oceans: experimental considerations. Limnol Oceanogr 31:673-689

Eppley RW, Peterson BJ (1979) Particulate organic matter flux and planktonic new production in the deep ocean. Nature 282:677-680

Falkowski PG, Laws EA, Barber RT, Murray JW (2003) Phytoplankton and their role in primary, new and export production. In: Fasham MJR (ed) Ocean biogeochemistry: the role of the ocean carbon cycle in global change. SpringerVerlag, Berlin, p 99-121

Fouilland E, Gosselin M, Rivkin RB, Vasseur C, Mostajir B (2007) Nitrogen uptake by heterotrophic bacteria and phytoplankton in Arctic surface waters. J Plankton Res 29:369-376

Grunseich GS, Dugdale RC, Breitner NF, MacIsaac JJ (1980) Sample conversion, mass spectrometry, and calculations for ${ }^{15} \mathrm{~N}$ analysis of phytoplankton nutrient uptake. CUEA Tech Rep 44:1-89

Harrison WG, Head EJH, Conover RJ, Longhurst AR, Sameoto DD (1985) The distribution and metabolism of urea in the eastern Canadian Arctic. Deep-Sea Res 32: $23-42$

Kanda J, Laws EA, Saino T, Hattori A (1987) An evaluation of isotope dilution effect from conventional data sets of ${ }^{15} \mathrm{~N}$ uptake experiments. J Plankton Res 9:79-90

Kirchman DL (2000) Uptake and regeneration of inorganic nutrients by marine heterotrophic bacteria. In: Kirch- man DL (ed) Microbial ecology of the oceans. Wiley-Liss, New York, p 261-288

Kirchman DL, Moss J, Keil RG (1992) Nitrate uptake by heterotrophic bacteria: does it change the f-ratio? Archiv Hydrobiol 37:129-138

Klein B, LeBlanc B, Mei ZP, Beret R and 12 others (2002) Phytoplankton biomass, production and potential export in the North Water. Deep-Sea Res II 49:4983-5002

Lee S, Furhman JA (1987) Relationship between biovolume and biomass of naturally derived marine bacterioplankton. Appl Environ Microbiol 53:1298-1303

Lee SH, Whitledge TE (2005) Primary and new production in the deep Canada Basin during summer 2002. Polar Biol 28:190-197

Legendre P, Legendre L (1998) Numerical ecology. Elsevier Science, Amsterdam

Legendre P, Vaudor A (1991) Le prologiciel R: analyse multidimensionnelle, analyse spatiale. Université de Montréal, Montréal

Lovejoy C, Legendre L, Price N (2002) Prolonged diatom blooms and microbial food web dynamics: experimental results from an Arctic polynya. Aquat Microb Ecol 29: $267-278$

MacIsaac J, Dugdale R (1972) Interaction of light and inorganic nitrogen in controlling nitrogen uptake in the sea. Deep-Sea Res 19:209-232

Mei ZP, Legendre L, Gratton Y, Tremblay JÉ, LeBlanc B, Klein B, Gosselin M (2003) Phytoplankton production in the North Water Polynya: size-fractions and carbon fluxes, April to July 1998. Mar Ecol Prog Ser 256:13-27

Melling H, Gratton Y, Ingram G (2001) Oceanic circulation within the North Water Polynya of Baffin Bay. AtmosOcean 39:301-325

Miller LA, Yager PL, Erickson KA, Amiel D and 8 others (2002) Carbon distributions and fluxes in the North Water, 1998 and 1999. Deep-Sea Res II 49:5151-5170

Mostajir B, Gosselin M, Gratton Y, Booth B and 5 others (2001) Surface water distribution of pico- and nanophytoplankton in relation to two distinctive water masses in the North Water, northern Baffin Bay, during fall. Aquat Microb Ecol 23:205-212

Parsons TR, Maita Y, Lalli CM (1984) A manual of chemical and biological methods for seawater analysis. Pergamon Press, Toronto

Price NM, Harrison PJ (1987) Comparison of methods for the analysis of dissolved urea concentrations in seawater. Mar Biol 94:307-317

Redfield AC, Ketchum BH, Richards FA (1963) The influence of organisms on the composition of sea-water. In: Hill MN (ed) The sea, Vol 2. Wiley, New York, p 26-77

Riley GA (1957) Phytoplankton of the north central Sargasso Sea, 1950-52. Limnol Oceanogr 2:252-270

Sambrotto RN, Mace BJ (2000) Coupling of biological and physical regimes across the Antarctic Polar Front as reflected by nitrogen production and recycling. Deep Sea Res II 47:3339-3367

Siegel DA, Doney SC, Yoder JA (2002) The North Atlantic spring phytoplankton bloom and Sverdrup's critical depth hypothesis. Science 296:730-733

Smith WO Jr (1995) Primary productivity and new production in the Northeast Water (Greenland) Polynya during summer 1992. J Geophys Res C 100:4357-4370

Smith WO Jr, Harrison WG (1991) New production in polar regions: the role of environmental controls. Deep-Sea Res 38:1463-1479

Smith WO Jr, Nelson DM (1990) Phytoplankton growth and new production in the Weddell Sea marginal ice zone 
in the austral spring and autumn. Limnol Oceanogr 35: 809-821

Smith WO Jr, Codispoti LA, Nelson DM, Manley T, Buskey EJ, Niebauer HJ, Cota GF (1991) Importance of Phaeocystis blooms in the high-latitude ocean carbon cycle. Nature 352:514-516

Smith WO Jr, Gosselin M, Legendre L, Wallace D, Daly K, Kattner G (1997) New production in the Northeast Water Polynya: 1993. J Mar Syst 10:199-209

Sokal RR, Rohlf JF (1981) Biometry. The principles and practice of statistics in biological research. WH Freeman, New York

Stirling I (1997) The importance of polynyas, ice edges, and leads to marine mammals and birds. J Mar Syst 10:9-21

Strickland JDH, Parsons TR (1972) A practical handbook of seawater analysis. Bull Fish Res Board Can 167

Editorial responsibility: Fereidoun Rassoulzadegan, Villefranche-sur-Mer, France
Tremblay JÉ, Gratton Y, Carmack EC, Payne CD, Price NM (2002a) Impact of the large-scale Arctic circulation and the North Water Polynya on nutrient inventories in Baffin Bay. J Geophys Res C 107:3112, doi: 10.1029/2000JC000595

Tremblay JÉ, Gratton Y, Fauchot J, Price NM (2002b) Climatic and oceanic forcing of new, net, and diatom production in the North Water. Deep-Sea Res II 49:4927-4946

Tremblay JÉ, Michel C, Hobson KA, Gosselin M, Price NM (2006) Bloom dynamics in early opening waters of the Arctic Ocean. Limnol Oceanogr 51:900-912

Wassmann P, Peinert R, Smetacek V (1991) Patterns of production and sedimentation in the boreal and polar Northeast Atlantic. Polar Res 10:209-229

Zar JH (1999) Biostatistical analysis. Prentice-Hall, Upper Saddle River, NJ

Submitted: August 21, 2006; Accepted: March 9, 2007 Proofs received from author(s): August 23, 2007 